\title{
The Prevalence of Huntington's Disease
}

\author{
Michael D. Rawlins ${ }^{a}$ Nancy S. Wexler ${ }^{b, c}$ Alice R. Wexler ${ }^{b}$ Sarah J. Tabrizid

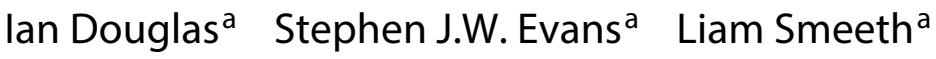 \\ ${ }^{a}$ Department of Non-Communicable Disease Epidemiology, London School of Hygiene and Tropical Medicine, \\ ${ }^{\mathrm{b}}$ Hereditary Disease Foundation, and ${ }^{\mathrm{C} C o l u m b i a}$ University, New York, USA; ${ }^{\mathrm{d}}$ Institute of Neurology, University \\ College London, London, UK
}

\section{Key Words}

Huntington's disease · Systematic review · Prevalence ·

Epidemiology

\begin{abstract}
Background: Reviews of the epidemiology of Huntington's disease (HD) suggest that its worldwide prevalence varies widely. This review was undertaken to confirm these observations, to assess the extent to which differences in caseascertainment and/or diagnosis might be responsible, and to investigate whether the prevalence pattern has changed over the past 50 years. Methods: Eighty two relevant studies were identified from Medline and Embase, previous reviews, scrutiny of references from included and excluded studies and enquiry among those interested in the field. Results: The lowest rates were among the Asians and the highest among the Caucasians. The differences are not fully explained by varying approaches to case-ascertainment or diagnosis. There was evidence of an increasing prevalence of between 15 and 20\% per decade in studies from Australia, North America and Western Europe. Conclusions: The prevalence of HD varies more than tenfold between different geographical regions. This variation can in part be attributed
\end{abstract}

to differences in case-ascertainment and/or diagnostic criteria, but there is consistent evidence of a lower incidence in Asian populations. There is also evidence that in Australia, North America and in Western Europe (including the United Kingdom), prevalence has increased over the past 50 plus years.

(c) 2016 S. Karger AG, Basel

\section{Introduction}

Huntington's disease (HD) is a hereditary neurological disorder inherited as an autosomal dominant trait [1, 2] because of an expanded trinucleotide repeat in a gene on chromosome 4p16.3 [3]. Although there is an unusually rare juvenile form of the condition [4], HD usually presents in early middle life with abnormal movements (particularly chorea) together with psychiatric symptoms including psychosis, depression, and obsessive-compulsive disorder together with progressive cognitive impairment $[1,2]$.

Estimates of the prevalence of HD suggest a more than tenfold difference between regions across the world. Three systematic reviews of the prevalence of HD appear

\section{KARGER}

E-Mail karger@karger.com

www.karger.com/ned
(C) 2016 S. Karger AG, Basel

0251-5350/16/0462-0144\$39.50/0 
to have been published. Of these, one was confined to sub-Saharan Africa [5], one only included studies conducted in the United Kingdom [6] after 1988, and the third [7] was confined to estimates undertaken between 1985 and 2010. The present systematic review was undertaken to identify all published estimates of the prevalence of HD between January 1930 and June 2015; to assess the heterogeneity of these estimates within and between geographical regions; and to determine the extent to which this might be explained by differences in case-ascertainment and/or approaches to diagnosis and/or other factors. The review also sought to establish whether the apparent increase in the prevalence of $\mathrm{HD}$, recently reported in the United Kingdom [8], occurs in other geographical regions.

\section{Methods}

The criteria for inclusion in the systematic review were that studies should have attempted to identify patients with HD among a population of more than 150,000 persons between 1930 and June 2015. This population exclusion criterion was introduced for 2 reasons. First, prevalence in smaller populations would provide unreliable estimates. Second, such studies include 'clusters' of HD families often living in small isolated communities some of which may possibly be descended from a single 'founder'. These reports were therefore excluded from the main review, but their descriptions have been included in 'discrete populations' (online suppl. material Annex 2; for all online suppl. material, see www.karger.com/ doi/10.1159/000443738).

Relevant publications (including published abstracts) were sought from a search of Medline and Embase databases (online suppl. material Annex 1). Publications were also sought from scrutiny of the references quoted in reviews of the epidemiology of HD [9-14] and by examining the reference lists of publications meeting the inclusion criteria. Reports described as 'personal communications' to the author of one review [11] were not, however, included. No studies were excluded by virtue of their date, or because of the approach taken to either case ascertainment or the diagnosis of HD. There were no language restrictions.

Relevant details included in publications that met the inclusion criteria were transcribed by MDR and ARW onto specially devised forms. The transcribed data recorded the following:

- The full reference.

- The geographical location of the study.

- The prevalence date(s).

- The source and size of the base population data.

- Case ascertainment methodology.

- Method(s) used in the diagnosis of HD.

- Number of HD patients identified.

The authors' estimate of the prevalence includes confidence intervals wherever provided.

For all included studies, the estimates of prevalence were recalculated together with their $95 \%$ binomial CIs. In some instances, although studies provided estimates of prevalence, they failed to indicate either the base population size or the number of HD patients. In these circumstances, the missing values were determined by back extrapolation.

The heterogeneity of different estimates of prevalence was estimated from the $\mathrm{I}^{2}$ test [15]. Relationships between study years, and the prevalence rates for those years, were assessed by Poisson regression analysis and trends were expressed as the percentage increase per decade. To avoid undue emphasis in favour of studies with estimates of prevalence rates covering more than 1 year, only the rate in the final year was used in the assessment of heterogeneity and in the trend analyses. Reporting followed, where appropriate, the PRISMA guidelines [16].

\section{Results}

The removal of duplicate publications, irrelevant reports, and reports among discrete populations yielded 83 studies with population estimates of the prevalence of HD. Further details of the studies in discrete populations are in online supplementary material Annexes 2 and 3. Other excluded studies are shown in online supplementary material Annexes 4 and 5. The study by Panse [17], carried out in the Rhineland between 1936 and 1937, met the pre-specified inclusion criteria but was excluded on ethical grounds. Friedrich Panse, a German psychiatrist, was deeply involved in the Nazi eugenics program that carried out coercive sterilization and extermination of persons with a wide range of psychiatric and neurological conditions including HD [18]. We consider that his participation in such a programme compromises his study on both ethical and scientific grounds and urge that future reviews of the epidemiology of HD also consider excluding this publication. Exclusion of this study left 82 publications for scrutiny and analysis (fig. 1; table 1). A summary of the geographical distribution of the included studies is shown in table 1.

The methods used for case ascertainment and the diagnosis of HD, for each included study, are shown in the online supplementary material Annexes 6-12. A variety of approaches have been adopted in identifying patients with HD in defined populations. Some have been based on a scrutiny of the records of hospitals and nursing homes. Others sought information from individual physicians. In some instances, cases were also identified by enquiry of the families of affected individuals. Case ascertainment in more recent studies was based on the records of medical genetics laboratories. We were unable, however, to devise a method that would have allowed quantitative analyses of various approaches to case ascertainment for this study.

In a majority of studies, the diagnosis of $\mathrm{HD}$ was based on clinical features supplemented, in more recent years, 


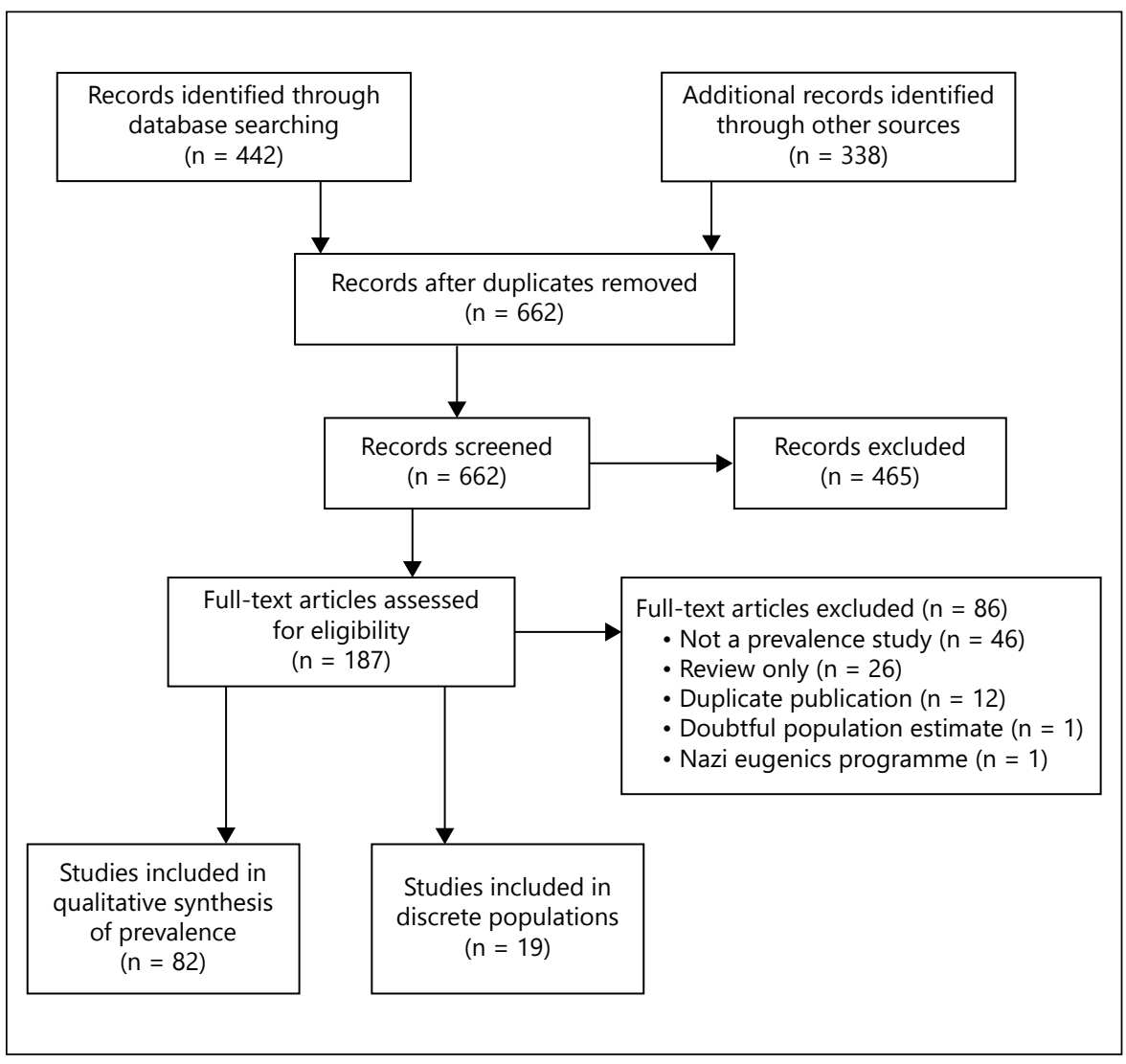

Fig. 1. Flow diagram of search strategy.

by the results of genetic analysis. Again, however, we were unable to develop an approach that would have provided a quantitative assessment of the reliability of the diagnostic approaches used in individual studies.

The estimates of prevalence across the 82 studies shows marked heterogeneity ( $\mathrm{I}^{2}=99.0 \%, 95 \%$ CI 98.9-99.1). Forest plots of prevalence rates by geographical region are shown in figures $2-8$. In all figures, the size of the point estimates of each study reflects their power. Further details of the studies, themselves, can be found in the online supplementary material Annexes 13-19. Summary results of the Poisson regression analyses of prevalence rates by study year (expressed in decades), for each geographical region, are shown in table 2 . This does not, however, include the 3 studies carried out in Africa as the number is too few (table 2) for reliable conclusions to be drawn.

\section{Africa}

Figure 2 (online suppl. material Annex 13) shows the prevalence of $\mathrm{HD}$ from studies undertaken in Africa. In the forest plot (fig. 2), the 'total' prevalence estimate by Hayden et al. [19], combining rates among Cape coloured,
Table 1. Summary of studies of the prevalence of HD

\begin{tabular}{lll}
\hline Region & $\begin{array}{l}\text { Included } \\
\text { prevalence } \\
\text { studies }\end{array}$ & $\begin{array}{l}\text { Discrete } \\
\text { populations }\end{array}$ \\
\hline Africa & 3 & 4 \\
Americas & 7 & 5 \\
Asia & 8 & 1 \\
Central and Eastern Europe & 8 & 1 \\
Oceania & 8 & 2 \\
United Kingdom & 21 & 4 \\
Western Europe (excluding & & 2 \\
$\quad$ the United Kingdom) & 27 & 19 \\
Totals & 82 & \\
\hline
\end{tabular}

white and black communities, has been omitted but is shown in Web-extra Annex 13. The data suggest that in South Africa, the prevalence of HD is similar among Cape coloureds and whites but appears to be substantially less in blacks [19]. The prevalence among the Bantu population of Zimbabwe [20] is reported to be greater than that among black South Africans. 
Fig. 2. Forest plot of prevalence: Africa.

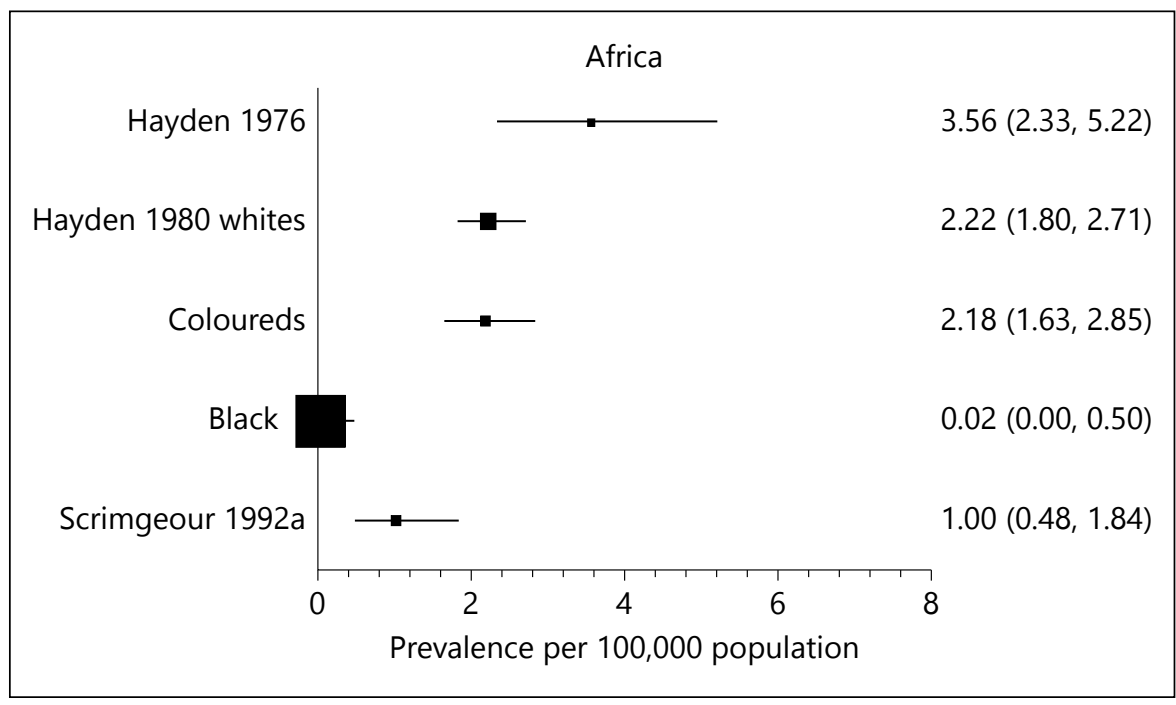

Fig. 3. Forest plot of prevalence: America $\left(\mathrm{I}^{2}=98.9 \%, 95 \%\right.$ CI 98.6-99.0).
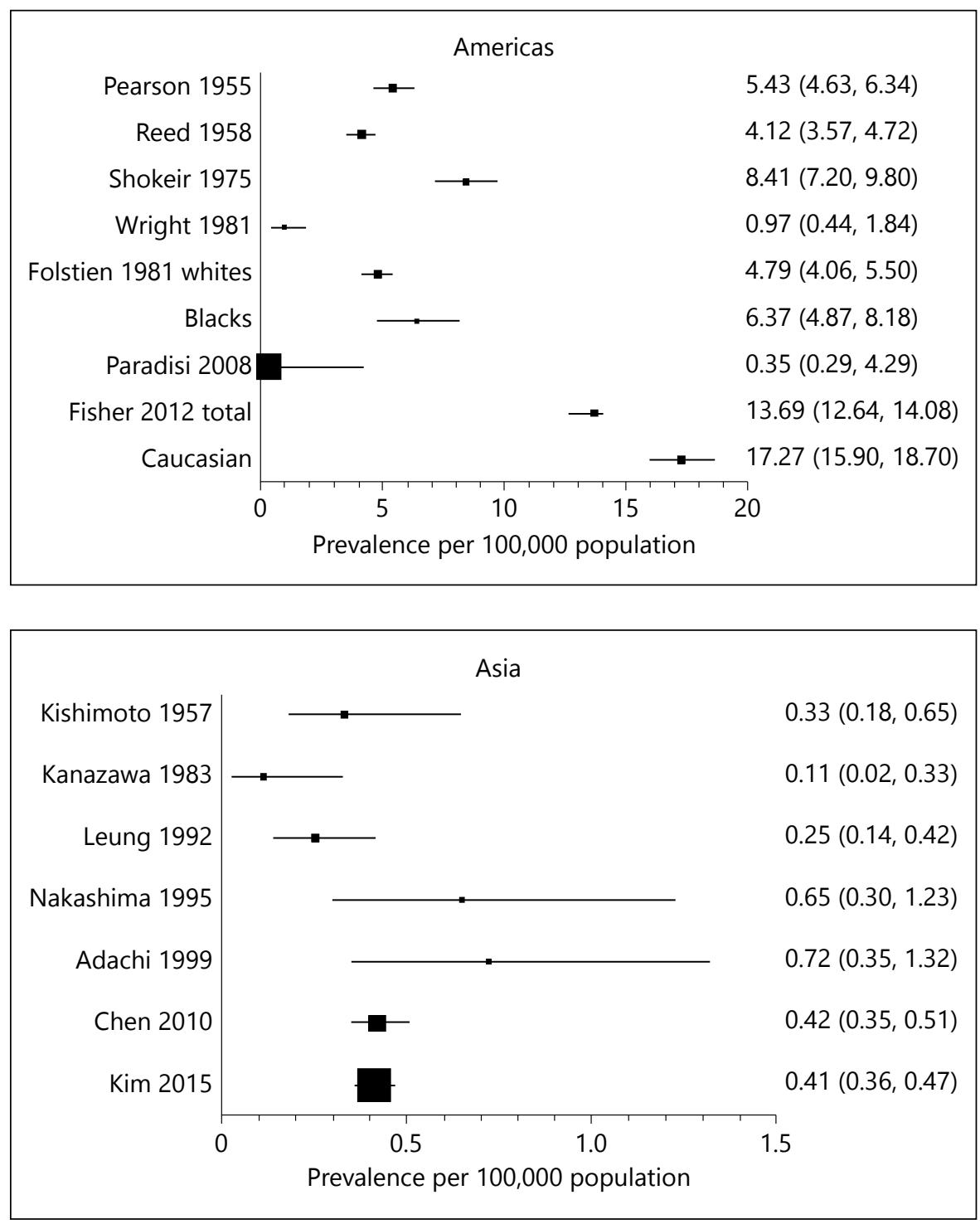

Fig. 4. Forest plot of prevalence: Asia $\left(\mathrm{I}^{2}=\right.$ $49.0 \%, 95 \%$ CI 0-76.6). 
Fig. 5. Forest plot of prevalence: Central and Eastern Europe $\left(\mathrm{I}^{2}=94.6 \%, 95 \% \mathrm{CI}\right.$ 92.1-96.0).
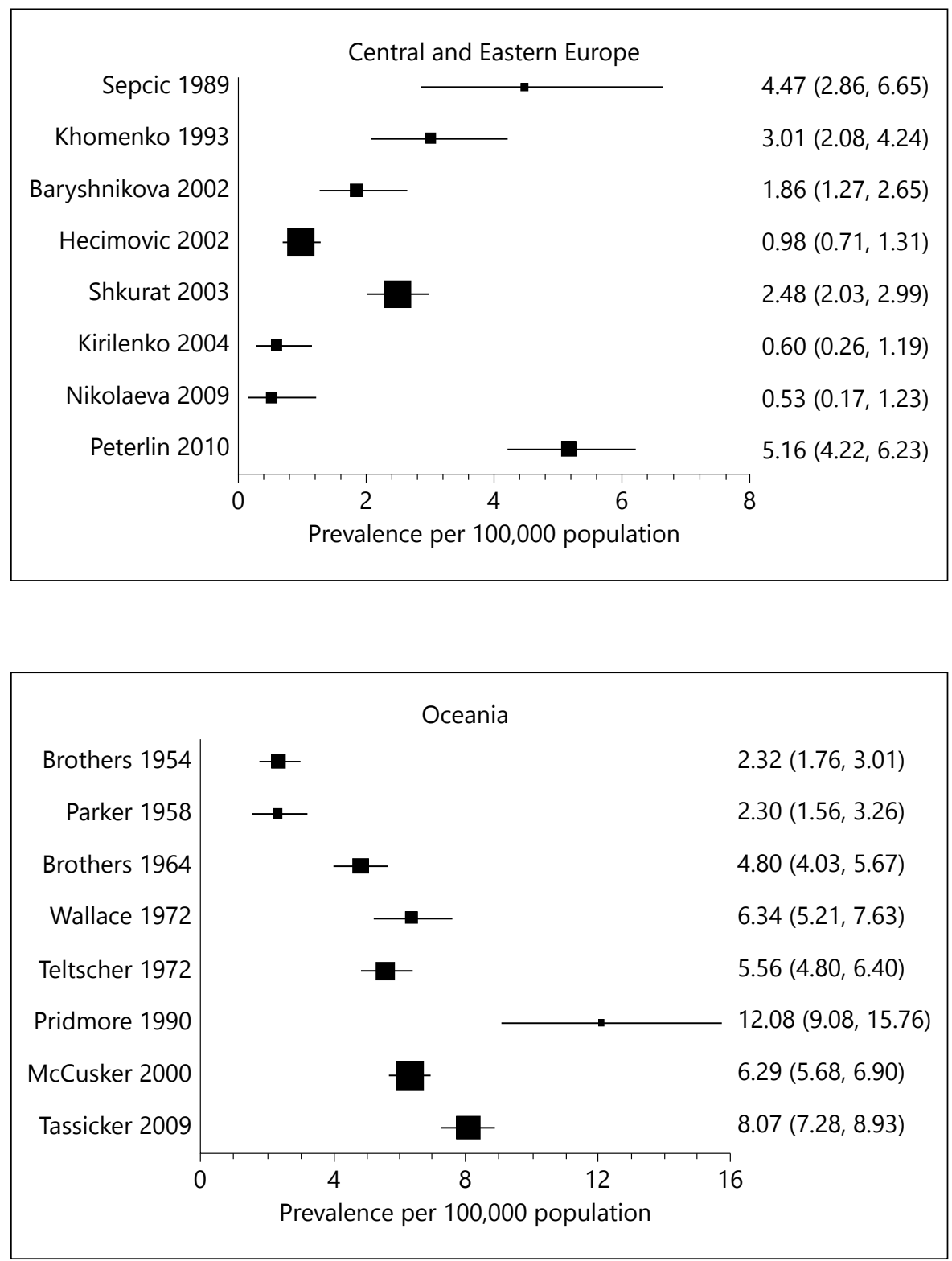

Fig. 6. Forest plot of prevalence: Oceania $\left(I^{2}=94.9 \%, 95 \%\right.$ CI 92.6-96.0). higher than those of blacks living in South African [19] and Zimbabwe [20] (0.02 and 1.00 per 100,000 respectively). Excluding the single study from South America [21], there was a significant trend in data from North America (table 2), between 1950 and 2012, for estimates of prevalence to increase with time $(20.1 \%, 95 \%$ CI $18.1-$ 22.1 per decade).

\section{Asia}

Figure 4 (online suppl. material Annex 15) shows prevalence rates in Hong Kong, Japan, South Korea and Taiwan. These range from 0.11 per 100,000 [24] to 0.72 


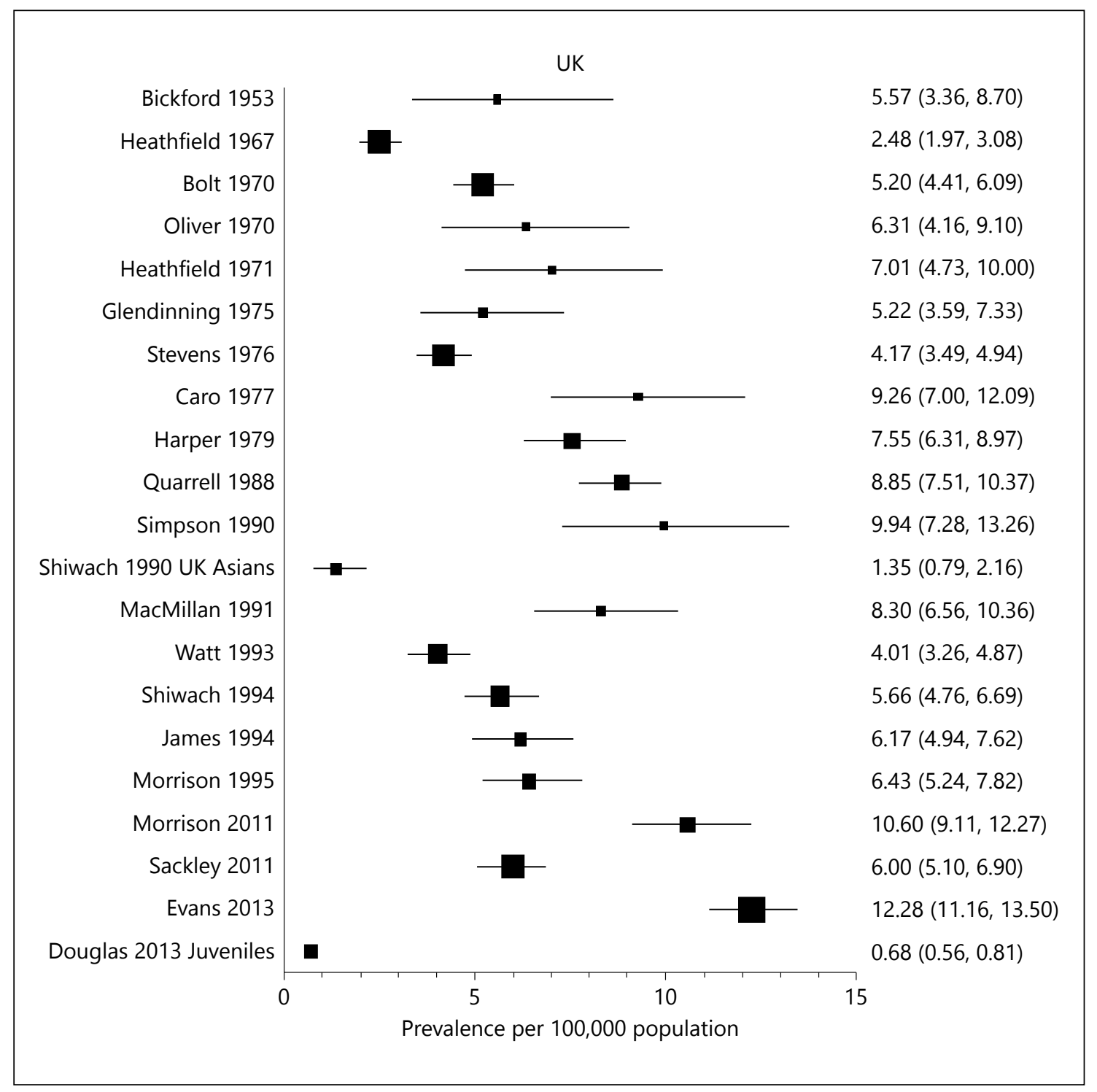

Fig. 7. Forest plot of prevalence: United Kingdom $\left(I^{2}=95.0 \%, 95 \%\right.$ CI 93.7-95.8).

per 100,000 [25] and are strikingly lower than those in most of Oceania, Western Europe and the United States. In addition, there was substantially less heterogeneity compared to other regions $\left(\mathrm{I}^{2}=49.0 \%, 95 \%\right.$ CI $\left.0-76.6\right)$. There was no significant trend between study years and estimates of prevalence (table 2).

\section{Central and Eastern Europe}

The marked heterogeneity of the prevalence rates of $\mathrm{HD}$ in Central and Eastern Europe $\left(\mathrm{I}^{2}=94.6 \%, 95 \% \mathrm{CI}\right.$ 92.1-96.0) can be seen in figure 5 (online suppl. material Annex 16). There was, however, no significant trend between study dates and prevalence estimates (table 2).

\section{Oceania}

The 8 included studies from Oceania were all undertaken in Australia between 1954 and 1999. There is marked heterogeneity (fig. 6; online suppl. web-extra Annex 17) in prevalence rates $\left(\mathrm{I}^{2}=94.9 \%, 95 \%\right.$ CI 92.6-96.2) as well as a significant trend (table 2 ) with study years (15.7\%, 95\% CI 11.9-19.6 per decade).

\section{United Kingdom}

Because of the large number of studies undertaken in Western Europe, as a whole, those from the United Kingdom are described separately. As can be seen from figure 7 (online suppl. material Annex 18) the included UK 


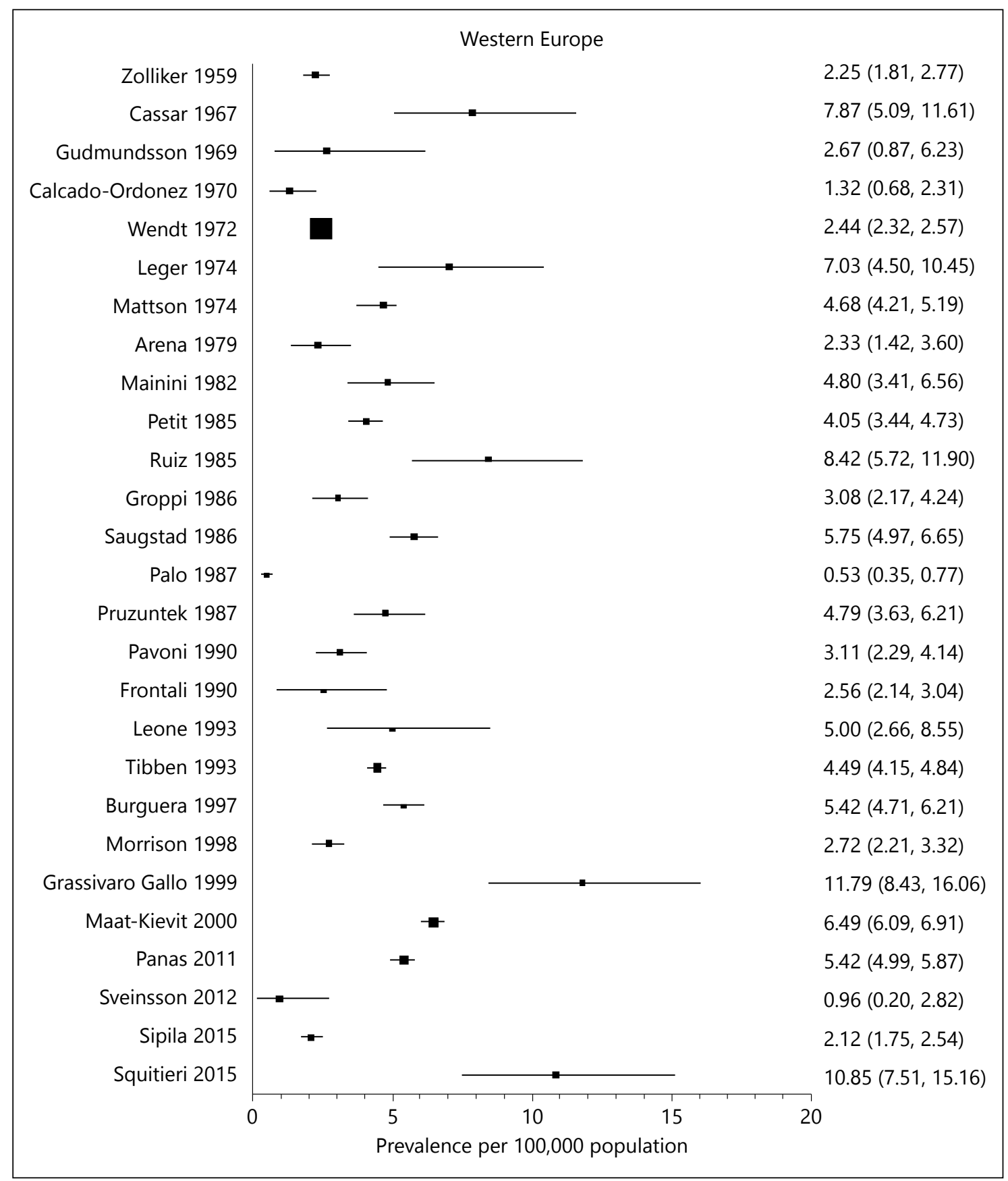

Fig. 8. Forest plot of prevalence: Western Europe (excluding the UK) ( $I^{2}=97.5,95 \%$ CI 97.2-97.8).

studies, conducted over a 60-year time-frame (1950-2013), show marked heterogeneity $\left(\mathrm{I}^{2}=95 \%, 95 \%\right.$ CI 93.7-95.8). Factors that contribute to the apparent discrepancies between the 2 most recent prevalence estimates for the United Kingdom have been discussed elsewhere [8]. It is striking that the estimate of prevalence in a study [26] confined to migrants from the Indian subcontinent $(1.35,95 \%$ CI
$0.79-2.16$ per 100,000 population) is substantially lower than other UK estimates of adult HD and is commensurate with the results from Asia. Excluding the studies confined to UK migrants from the Indian subcontinent [26], and those with the juvenile form of HD [27], there is a significant trend (table 2) of 15.5\% (95\% CI 11.3-18.0) per decade between study dates and the estimates of prevalence. 
Table 2. Prevalence rate ratios

\begin{tabular}{lllll}
\hline & $\begin{array}{l}\text { Number of studies } \\
\text { in estimates } \\
\text { of rate ratios }\end{array}$ & $\begin{array}{l}\text { Study years } \\
\text { (range) }\end{array}$ & $\begin{array}{l}\text { Average prevalence } \\
\text { per 100,000 } \\
(95 \% \text { CIs) }\end{array}$ & $\begin{array}{l}\text { Trend (percent) by } \\
\text { decade }\end{array}$ \\
\hline Asia & 7 & $1957-2013$ & $0.40(0.36-0.44)$ & $8.9(-2.24$ to +23.8$)$ \\
Central and Eastern Europe & 8 & $1981-2008$ & $2.17(1.95-2.41)$ & $15.4(2.70$ to +38.6$)$ \\
North America & 6 & $1950-2012$ & $7.33(6.94-7.74)$ & $20.1(+18.1$ to 22.1$)$ \\
Oceania & 8 & $1981-2008$ & $5.63(5.61-6.25)$ & $15.4(+11.6$ to +19.3$)$ \\
United Kingdom & 19 & $1950-2010$ & $6.68(6.40-6.97)$ & $15.5(+11.3$ to +18.0$)$ \\
Western Europe & 27 & $1930-2013$ & $3.60(3.50-3.69)$ & $16.5(+14.9$ to +18.6$)$ \\
\hline
\end{tabular}

Western Europe (Excluding the United Kingdom)

The prevalence rates in the rest of Western Europe are shown in figure 8 (online suppl. material Annex 19). Again, there is marked heterogeneity $\left(\mathrm{I}^{2}=97.5 \%, 95 \% \mathrm{CI}\right.$ 97.2-97.8) with estimates ranging from 0.53 per 100,000 in Finland [28] to 10.85 per 100,000 in Italy [29]. There was, overall, a significant trend (table 2) between the study dates and prevalence estimates $(16.3 \%$, 95\% CI 14.8-18.4 per decade).

\section{Discrete Populations}

The studies of HD in discrete populations, shown in the online supplementary material Annex 2, fall into 2 groups. Some [30-35] describe clusters of HD families, living in small communities, often with suggestions that affected individuals are those who have descended from a single progenitor. The remaining studies describe estimates of prevalence in populations of less than 150,000.

\section{Discussion and Conclusions}

The global population prevalence of HD appears to show a more than tenfold variation across regions. The very low prevalence rates among blacks in South Africa $(0.02,95 \%$ CI $0-0.5$ per 100,000) [19] and Zimbabwe $(1.00,95 \%$ CI $0.48-1.84$ per 100,000$)$ [20] may be due to weak case ascertainment in communities with limited healthcare provision. In North America, Folstein et al. [23] reported prevalence among blacks of 6.37 (95\% CI $4.87-8.18)$ per 100,000 and in whites of 4.79 (95\% CI $4.06-5.60)$ per 100,000 . The similarity between the estimates of prevalence among blacks and whites in North America may be due, at least in part, to mixed race ancestry. The low prevalence rates of HD in Hong Kong, Japan, and Taiwan (fig. 5; online suppl. web-extra Annex 16) are very unlikely to be due to poor case ascertainment or inadequate diagnoses because all have relatively high levels of healthcare provision. The average prevalence rate since 1995 - when genetic testing came into routine use - in Asians countries (Hong Kong, Japan, South Korea and Taiwan) was 0.42 (95\% CI $0.37-0.47)$ per 100,000 . By comparison, the average prevalence rate for the same period, among predominantly Caucasian populations (in Australia, Western Europe including the United Kingdom and North America, was 9.71 (95\% CI 9.32-10.12) per 100,000 . Moreover, as discussed earlier, the UK study among UK immigrants from the Indian subcontinent also showed a substantially lower prevalence [26] than the prevalence that existed in the United Kingdom as a whole. Reduced mutation rates may be responsible for the lower prevalence rates of $\mathrm{HD}$ in East Asians. It has been suggested $[36,37]$ that different haplotypes, between East Asians and Europeans, may be associated with differing mutation rates. Sipila et al. [38] suggest that the lower prevalence of HD in Finland may also be due to differences in haplotype. Further research, however, is needed to explain these marked global differences in prevalence.

Our previous study of the prevalence of HD in the United Kingdom [7] showed that prevalence rates have increased more than twofold between 1990 and 2010. The present study indicates that apparent prevalence rates of HD have increased (table 2) by around $15-20 \%$ per decade in Australia (between 1954 and 1996), North America (between 1950 and 2012), the United Kingdom (between 1950 and 2010) and other countries in Western Europe (between 1930 and 2007). There is no suggestion that prevalence has increased significantly in Asia or Central and Eastern Europe. This may be due to the relatively small number of studies reported in these 2 regions or, at least for Asia, because of the lower prevalence of $\mathrm{HD}$ more generally. 
The rise in prevalence of $\mathrm{HD}$ in Australia, North America, the United Kingdom and Western Europe, is likely to have a number of causes. First, physicians' better knowledge and awareness of HD, complemented by the availability of a genetic test to indicate the genetic status of individuals [2], may have increased the rates of diagnosis particularly in older patients and those with no known family history of HD [39-42]. Second, it is also possible that the 'shame' traditionally associated with a family history [43] of HD has diminished, and that physicians have become less reluctant to record an HD diagnosis. Third, the increased prevalence might be due to increased mutation rates, with a corresponding increase in incidence. A recent study by us, however, based on data from the United Kingdom [44] suggests that the incidence of HD between 1990 and 2010 has remained unchanged. Fourth, it is likely that the general increase in population survival will have had some effect on the longevity of those with HD, thus increasing prevalence even in the absence of a rise in incidence. In addition, the availability of more effective symptomatic treatments for HD (including antidepressants, antipsychotics, and anti-choreiform medication) may have also had an additional impact on survival.

Irrespective of the explanation it behoves healthcare systems in Australia, North America and Western Europe (including the United Kingdom) to ensure that appropriate facilities are available for the care of patients with HD.
It is uncertain as to whether all the reported 'clusters' of people with HD, in villages and townships in South America and Europe, have persisted as reports date back many years. Certainly many people with HD are known to still live in the 'clusters' in Colombia and Venezuela. For these individuals, their families and their communities countries' healthcare systems should strive even further, to ensure appropriate services are available for their care.

\section{Funding}

This work was supported by the Hereditary Disease Foundation, the Medical Research Council and the Wellcome Trust.

\section{Disclosure Statement}

None.

\section{Acknowledgements}

We acknowledge with gratitude the following colleagues for their help in translating of a number of publications: Dr. Françoise Cluzeau (French), Dr. Elizabeth George (German), Leeza Osipenko (Russian), Dr. Francis Ruiz (Spanish) and Professor Giampaulo Velo (Italian).

\section{References}

1 Novak MJ, Tabrizi SJ: Huntington's disease. BMJ 2010;341:34-40.

2 Wexler NS: Huntington's disease: advocacy driving science. Annu Rev Med 2012;63:1-22.

3 A novel gene containing a trinucleotide repeat that is expanded and unstable on Huntington's disease chromosomes. The Huntington's Disease Collaborative Research Group. Cell 1993;72:971-983.

4 Quarrell O, O'Donovan KL, Bandmann O, Strong M: The prevalence of juvenile Huntington's disease: a review of the literature and meta-analysis. PLoS Curr 2012;4:e4f8606b742ef3.

5 Lekoubou A, Echouffo-Tcheugui JB, Kengne AP: Epidemiology of neurodegenerative diseases in sub-Saharan Africa: a systematic review. BMC Public Health 2014;14:653.

6 Hoppitt T, Pall H, Calvert M, Gill P, Yao G, Ramsay J, James G, Conduit J, Sackley C: A systematic review of the incidence and prevalence of long-term neurological conditions in the UK. Neuroepidemiology 2011;36:1928.

7 Pringsheim T, Wiltshire K, Day L, Dykeman $\mathrm{J}$, Steeves T, Jette N: The incidence and preva- lence of Huntington's disease: a systematic review and meta-analysis. Mov Disord 2012;27: 1083-1091.

8 Evans SJ, Douglas I, Rawlins MD, Wexler NS, Tabrizi SJ, Smeeth L: Prevalence of adult Huntington's disease in the UK based on diagnoses recorded in general practice records. J Neurol Neurosurg Psychiatry 2013;84: 1156-1160.

9 Conneally PM: Huntington disease: genetics and epidemiology. Am J Hum Genet 1984;36: 506-526.

10 Harper PS: The epidemiology of Huntington's disease. Hum Genet 1992;89:365-376.

11 Harper PS: The epidemiology of Huntington's disease; in Bates G, Harper PS, Jones L (eds): Huntington's Disease, ed 3 Oxford, Oxford University Press, 2002.

12 Al-Jader LN, Harper PS, Krawczak M, Palmer SR: The frequency of inherited disorders database: prevalence of Huntington disease. Community Genet 2001;4:148-157.

13 Centre for Molecular Medicine and Therapeutics. Published reports of the worldwide prevalence of Huntington's disease. Univer- sity of British Columbia, 2011. www.cmmt. ubc.ca/research/diseases/huntingtons/HD Prevalence.

14 Kay C, Fisher E, Hayden MR: Epidemiology; in Bates GP, Tabrizi SJ, Jones L (eds): Huntington's Disease, ed 4. Oxford, Oxford University Press, 2014.

15 Higgins J, Thompson SG, Deeks JJ, Altman DGL: Measuring inconsistency in meta-analysis. BMJ 2003;327:557-560.

16 Moher D, Liberati A, Tetzlaff J, Altman DG PRISMA Group: Preferred reporting items for systematic reviews and meta-analyses: the PRISMA statement. PLoS Med 2009; 6:e1000097.

17 Panse F, Die erbchorea: eine klinische-genetische studie Leipzig, Thieme, 1942.

18 Forsbach R: Friedrich Panse - etabliert in allen Systemen: Psychiater in der Weimarer Republik, im 'Dritten Reich' und in der Bundesrepublik. Der Nervenarzt 2012;83: 329-336.

19 Hayden MR, MacGregor JM, Beighton PH: The prevalence of Huntington's chorea in South Africa. S Afr Med J 1980;58:193-196. 
20 Scrimgeour EM, Pfumojena JW: Huntington disease in black Zimbabwean families living near the Mozambique border. Am J Med Genet 1992;44:762-766.

21 Paradisi I, Hernández A, Arias S: Huntington disease mutation in Venezuela: age of onset, haplotype analyses and geographic aggregation. J Hum Genet 2008;53:127-135.

22 Fisher ER, Hayden MR: Multisource ascertainment of Huntington disease in Canada: prevalence and population at risk. Mov Disord 2014;29:105-114.

23 Folstein SE, Chase GA, Wahl WE, McDonnell AM, Folstein MF: Huntington disease in Maryland: clinical aspects of racial variation. Am J Hum Genet 1987;41:168-179.

24 Kanazawa I: Prevalence and Rate of Huntington's Disease in Ibaraki Prefecture. Annual Report of the Research Committee of CNS Degenerative Diseases. Ministry of Health and Welfare of Japan, 1983, pp 151-156.

25 Adachi Y, Nakashima K: [Population genetic study of Huntington's disease - prevalence and founder's effect in the San-in area, western Japan]. Nihon Rinsho 1999;57:900904.

26 Shiwach RS, Lindenbaum RH: Prevalence of Huntington's disease among UK immigrants from the Indian subcontinent. Br J Psychiatry 1990;157:598-599.

27 Douglas I, Evans S, Rawlins MD, Smeeth L, Tabrizi SJ, Wexler NS: Juvenile Huntington's disease: a population-based study using the general practice research database. BMJ Open 2013;3:e002085.
28 Palo J, Somer H, Ikonen E, Karila L, Peltonen L: Low prevalence of Huntington's disease in Finland. Lancet 1987;2:805-806.

29 Squitieri F, Griguoli A, Capelli G, Porcellini A, D'Alessio B: Epidemiology of Huntington disease: first post-HTT gene analysis of prevalence in Italy. Clin Genet 2015, Epub ahead of print.

30 Avila-Giron R: Medical and social aspects of Huntington's chorea in the state of Zulia, Venezuela. Adv Neurol 1973;1:261-266.

31 Hardt P: Persons with Huntington's disease jailed in Juan de Costa. Huntington's Disease Advocacy Centre. http://www.ruledomain. com/hdac/features/article.php?p_articleNumber $=641$.

32 Alencar MA, Lopez AM, Figueiredo E, Porciúncula CG, Monlleó I: Prevalence of Huntington's disease in Feira Grande, a small city in northeastern Brazil. J Neurol Neurosurg Psychiatry 2010;81:A22.

33 Kozlova SI, Dadali EL, Prytkov AN, Bol'shakova LP, Sibiriakova LG: Populiatsionno-demograficheskaia i kliniko-geneticheskaia kharakteristika khorei Gentingtona v odnom iz raionov Azerbaijana. Genetika 1986;22:2534-2539.

34 Lyon RL: Huntington's chorea in the Moray Firth area. Br Med J 1962;1:1301-1306.

35 Sjogren T: Vererbungsmedizinische Untersuchungen uber Hunington's Chore in einer schwedischen Bauernpopulation. Zeitscr. F Menschl Vererbungs U Konstitutionslehre 1936;32:10-165.

36 Warby SC, Visscher H, Collins JA, Doty CN, Carter C, Butland SL, Hayden AR, Kanazawa I, Ross CJ, Hayden MR: HTT haplotypes contribute to differences in Huntington disease prevalence between Europe and East Asia. Eur J Hum Genet 2011;19:561-566.
$37 \mathrm{Xu} \mathrm{M}, \mathrm{Wu} \mathrm{ZY}$ : Huntington disease in Asia. Chin Med J (Engl) 2015;128:1815-1819.

38 Sipila JO, Hietala M, Siitonen A, Päivärinta M, Majamaa K: Epidemiology of Huntington's disease in Finland. Parkinsonism Relat Disord 2015;21:46-49.

39 Almqvist EW, Elterman DS, MacLeod PM, Hayden MR: High incidence rate and absent family histories in one quarter of patients newly diagnosed with Huntington disease in British Columbia. Clin Genet 2001;60:198205.

40 Ramos-Arroyo MA, Moreno S, Valiente A: Incidence and mutation rates of Huntington's disease in Spain: experience of 9 years of direct genetic testing. J Neurol Neurosurg Psychiatry 2005;76:337-342.

41 Koutsis G, Karadima G, Kladi A, Panas M: Late-onset Huntington's disease: diagnostic and prognostic considerations. Parkinsonism Relat Disord 2014;20:726-730.

42 Cornejo-Olivas MR, Inca-Martinez MA, Espinoza-Huertas K, Veliz-Otani D, Velit-Salazar MR, Marca V, Ortega O, Cornejo-Herrera IF, Lindo-Samanamud S, Mora-Alferez P, Mazzetti P: Clinical and molecular features of late onset Huntington disease in a Peruvian cohort. J Huntingtons Dis 2015;4:99-105.

43 Wexler AR: The Woman Who Walked into the Sea: Huntington's and the Making of a Genetic Disease. New Haven, Yale University Press, 2008.

44 Wexler NS: The incidence of Huntington's disease: a UK-based population study and a systematic review. BMJ Open, in press. 